\title{
Graciliano Ramos e as aporias do PERDÃO
}

Gustavo Silveira Ribeiro

Universidade Federal de Minas Gerais

\section{Resumo}

O ensaio propõe ler a autobiografia Infância, de Graciliano Ramos, como um espaço de reflexão sobre a experiência paradoxal do perdão. Tomando como base a elaboração teórica desenvolvida por Jacques Derrida sobre o tema, a análise procura privilegiar as passagens em que Graciliano Ramos ao mesmo tempo rememora e desfaz as violências de que foi vítima, procurando reconsiderá-las a partir de outros pressupostos éticos.

\section{Abstract}

This essay seeks to read Infância (Childhood), an autobiography by Graciliano Ramos, as a space to reflect on the paradoxical experience of forgiveness. Taking as basis the theoretical elaboration on the same theme by Jacques Derrida, the analysis will privilege the passages in which Graciliano Ramos at the same time remembers and disentangles the violence that victimized him, as he seeks to consider them from other ethical presuppositions.

\section{Palavras-chave}

Perdão, memória, paradoxo, violência, Infância, Graciliano Ramos.

\section{Keywords}

Forgiveness, memory, paradox, violence, Infância, Graciliano Ramos. 


\section{Experiência do impossível}

Perdoar é, em certo sentido, esquecer. Esquecer o agravo sofrido, a dor observada, a humilhação experimentada, sempre em função de um desejo (de um imperativo?) de reconciliação e apaziguamento. Perdoar, no entanto e ambiguamente, é também lembrar-se, ter plena consciência do que foi vivido com terror para que, desse modo, tal evento possa ser entendido de maneira plena, observado sob todos os seus ângulos, digerido, enfim, apesar de toda a carga de associações e lembranças negativas a que está relacionado. Dividido entre tais polos opostos, cindido entre essas duas instâncias e impulsos contraditórios e complementares, o perdão - como conceito e como prática histórica - se inscreve sob o signo do paradoxo e da indecidibilidade. Significativamente, tal condição imponderável do perdão faz com que tal conceito revele-se bastante apropriado para ler o livro de memórias Infância (1945), de Graciliano Ramos, texto urdido sob o signo de uma divisão agônica, de um conflito irresolvível (virtualmente impossível de resolver) entre a urgência das lembranças dolorosas do passado - que se impõem sobre o sujeito da escrita - e a necessidade, igualmente imperiosa, de esquecer e ressignificar o tempo e a experiência, dando outro sentido a si e ao seu texto, ao inventar a ambos com os olhos fixos no presente. As intrincadas questões que circundam o conceito (quem pode, ou deve, pedir perdão? E a quem caberia - se é que se trata aqui de um dever, de um direito ou de um ato de fé - conceder o perdão?), por sua vez, só vêm intensificar o seu aspecto aporético pelas dificuldades adicionais que aportam, de modo especial quando entendidos à luz ambígua e poderosa de um texto literário como o do escritor alagoano. Antes, porém, de aprofundar as aproximações e contrastes entre as duas instâncias - o discurso filosófico e o literário - voltemo-nos um instante para o primeiro termo dessa operação crítica.

Ligado, a um só tempo, a uma força dispersiva que visa destruir e desorganizar a cronologia, trazendo à tona eventos há muitos adormecidos para que eles, finalmente, possam ser redimensionados pelo sujeito ou por uma qualquer comunidade, que se dispõe assim a suspender e cancelar (sem jamais apagar de todo) os eventos traumáticos de que foi vítima, o perdão se liga também a uma potência convergente que visa homogeneizar afirmativamente, mesmo que de modo precário, a imagem que um determinado acontecimento histórico ou personagem possui junto àqueles que se sentiram, no instante presente ou a posteriori, prejudicados por suas ações ou consequências políticas e sociais. É como se o perdão pudesse, além de os por em estado de suspensão permanente, modificar a feição e o status da dívida e do devedor, fazendo com que eles sejam capazes de ser reintegrados ao fluxo cotidiano da vida, sem o estigma e a punição infinitas que recaem muitas vezes sobre indivíduos, grupos sociais ou nações inteiras que ofenderam ou praticaram crimes contra outrem. Dilacerado entre esses dois polos, que se desdobram, por sua vez, em muitos outros dilemas práticos e teóricos, o perdão não carrega, ao contrário do que se costuma pensar, a energia pacificadora que a ele se atribui comumente. O conflito é a sua natureza e o seu campo de ação, por mais contraditório que isso possa parecer.

Tendo sua origem vinculada às chamadas religiões do Livro (Judaísmo, Cristianismo e o Islã), todas elas monoteístas e de vasta tradição doutrinária, o perdão guarda em seu cerne inegável proximidade com o pensamento teológico. A ideia da reconciliação, da re-ligação entre Deus e os homens (ou entre os próprios homens), que atravessa o discurso e os mitos fundadores dessas religiões - veja-se, nesse sentido, o Yom Kippur (Dia do Perdão) judaico e a instituição, pelo próprio Cristo, do sacramento da confissão - está na base do conceito de que aqui se trata, estabelecendo as condições mínimas para que ele possa ser pensado. Nesse sentido, e a partir de um ponto de vista estritamente teológico, perdoar é retraçar caminhos, reconectar os laços partidos em busca, sempre, de uma totalidade. Associado a isso está também o problema da mediação divina, que aqui atua, simbolicamente, na resolução de um conflito 
que inexoravelmente surge junto com a problemática do perdão: quem pode perdoar, e em nome de que ou de quem esse ato de reconexão deve ser feito?

A partir do momento em que Deus ocupa o lugar de ponto de referência e justificação última do perdoar, a intrincada e no limite impossível questão do direito e da autoridade relativa ao perdão nem mesmo se coloca: a Deus cabia perdoar os homens, e aqueles que o faziam uns em relação aos outros também o faziam perante Deus e por Deus, não precisando, portanto, fundamentar os seus atos jurídica, política ou afetivamente. No mundo cada vez mais laico surgido desde, pelo menos, o século das Luzes, entretanto, no qual não existe um sistema de valores que se justifique e imponha a si mesmo de modo inquestionável, o perdão, como gesto fundamentalmente transcendente, torna-se ato problemático, sempre dependente de critérios racionais e de instrumentos institucionais para que possa efetivar-se. Tendo em mente esse quadro, podemos concluir que o conceito carrega em si mais do que uma simples herança teológica: as questões concernente à fé vão marcar de maneira decisiva a sua constituição, apontando alguns de seus limites e sentidos primordiais.

Se o perdão nasce e se estrutura, num primeiro momento, associado a circunstâncias de natureza espiritual, ele não está, todavia, limitado aos seus dogmas. Tanto o conceito quanto a práxis dele derivada penetraram a cultura do Ocidente e além, transformando-se não apenas num ritual (público ou privado) de arrependimento e culpa, mas também num tema de reflexão moral que se desdobrou ao longo dos tempos e assumiu diversas outras configurações. Hegel, na Fenomenologia do espírito, Sören Kierkegaard, no Temor e tremor, e Friedrich Nietzsche na Genealogia da moral ${ }^{1}$ foram alguns dos filósofos que se debruçaram sobre a questão no âmbito do século XIX, buscando observar os seus significados e implicações no processo de formação da subjetividade e da consciência, bem como da escala de valores morais que organizavam a vida humana. No século XX, Hannah Arendt (Eichmann em Jerusalém; Responsabilidade e julgamento), Vladimir Jankelévitch (Le Pardon)2, Jean Améry (Além do crime e do castigo) e Paul Ricouer (A memória, a história, o esquecimento) ${ }^{3}$, motivados por outros impasses históricos - quase todos ligados aos dramáticos eventos que, como a Shoah e as Guerras Coloniais, deram ao século o rosto terrível da catástrofe - foram alguns dos que também procuraram pensar o perdão para além do horizonte da teologia, percebendo a sua proximidade com a questão do Mal, da política internacional e da temporalidade, metafisicamente inquirida.

Herdeiro dessa nada desprezível tradição, o filósofo franco-argelino Jacques Derrida também procurou pensar o conceito na contemporaneidade, em seus textos e seminários da École de Hautes Études en Sciences Sociales, (um deles, inclusive, nomeado Le Pardon et le Parjure) para além dos estreitos marcos da religião, analisando-o, de maneira inseparável, tanto como fenômeno histórico do mundo presente quanto como questão filosófica que mobiliza, de uma só vez, o passado e a memória, a linguagem e a ética. Presente pelo menos desde o início dos anos 1990 em suas reflexões, o perdão, em Derrida, é elaborado como um paradoxo: materializando-se em ações concretas, em atos públicos de mea culpa pronunciados por chefes de Estado ou líderes religiosos de inúmeras nações, além de figurar na pauta do dia de muitos países que se debatem com o complexo legado e as marcas vivas deixadas por regimes autoritários ou eventos traumáticos, o perdão inscreve-se também como "experiência do impossível", ${ }_{4}^{4}$ como conceito que desafia o pensamento e ato cuja realização plena está sempre mais além dos limites fixados pela razão e pelo Direito.

\footnotetext{
${ }^{1}$ NIETZSCHE, Friedrich. Genealogia da Moral. Trad. Paulo Cesar Souza. São Paulo: Companhia das Letras, 2004.

2 JANKELÉVITCH, Vladimir. Le Pardon. Paris: Aubier, 1993.

${ }^{3}$ RICOUER, Paul. A memória, a história, o esquecimento. Trad. Alain François. Campinas: Ed. UNICAMP, 2007.

${ }^{4}$ DERRIDA, Jacques. Força de lei. O fundamento místico da autoridade. Trad. Leyla Perrone-Moisés. São Paulo: Martins Fontes, 2007, p.73.
} 
Conforme propõe o filósofo, o perdão, como instrumento de reflexão ética, deve desligar-se, ou ser desligado, de dois elementos que o constituem: por um lado, a busca pela reconciliação de uma totalidade perdida; por outro, a lógica econômica que o rege muitas vezes, lógica que impõe certas condições - arrependimento, promessa de regeneração, desejo de ser perdoado - para que ele se efetive. Nem cálculo, nem unidade. Para ele o perdão

não é puro, nem o é o seu conceito. O perdão não é, não deveria ser, nem normal, nem normativo, nem normatizante. Deveria permanecer excepcional e extraordinário, submetido à prova do impossível: como se interrompesse o curso ordinário da temporalidade histórica. ${ }^{5}$

O perdão permanece para Derrida como événement (acontecimento abrupto, imprevisível), uma irrupção performática da linguagem e do pensamento que não se deixa capturar pelas malhas discursivas tradicionais, erigidas em torno de definições claras e precisas, estáveis e sempre idênticas a si mesmas. Ele vai ser trabalhado como uma irrupção, algo da ordem do transcendental que entretanto se concretiza, torna-se uma possibilidade. Entre idas e vindas, entre a leitura de eventos singulares ${ }^{6}$ e a desconstrução de proposições generalizáveis, o perdão surge e se impõe a partir da análise do que o filósofo chamou de "uma urgência universal da memória", ${ }^{7}$ uma tendência geral (manifesta nas últimas décadas) à elaboração de pedidos de desculpa oficiais e à concessão de indenizações a indivíduos ou comunidades vitimadas pelos chamados Crimes contra a Humanidade: tortura, genocídio, perseguições políticas e atrocidades de guerra. Localizando nesse fenômeno ao mesmo tempo geopolítico, histórico, cultural e diplomático o recrudescimento de um problema filosófico (de origem abraâmica, logo mítica) que se manifesta agora em contextos em que as religiões do Livro não são relevantes (caso, por exemplo, do Japão e da Coreia, países que se dedicaram a repensar, recentemente, a memória e as consequências dos crimes praticados durante a Segunda Guerra Mundial), o autor procura investigar os significados desses gestos à luz não apenas de suas motivações particulares e interessadas, mas das perspectivas abertas pelo resgate do perdão num tempo e numa cultura fundamentalmente laicas.

\footnotetext{
${ }_{5}^{5}$ DERRIDA, Jacques. El siglo y el perdón (seguido de Fe y saber). Trad. Cristina de Peretti \& Paco Vidarte. Buenos Aires: Ediciones de la Flor, 2006, 12; grifo do autor.

${ }^{6}$ Um dos casos singulares mais cuidadosamente analisados por Derrida é, sem dúvida, o da África do Sul, país que o autor visitou quando ministrava seminário sobre o Perdão e o Perjúrio na EHESS. Além da admiração pública que nutria por Nelson Mandela (estadista que, uma vez liberto da prisão que o deteve durante 27 anos, negociou habilmente o processo de transição democrática que teve lugar em seu país, evitando a guerra civil que, aos olhos do mundo e de muitos dos próprios sul-africanos, parecia inevitável), o filósofo admirava também, embora com reservas e depois de fazer-lhe inúmeras críticas, a Comissão Verdade e Reconciliação (Truth and Reconciliation Comission - TRC), dirigida pelo bispo anglicano Desmond Tutu. Essa Comissão tinha a controversa e virtualmente impossível tarefa de fazer justiça às vítimas do apartheid ao mesmo tempo em que preparava, junto ao governo Mandela, o processo de transição política que incluiu desde a primeira hora a questão da Anistia. Lidando com os dois lados do problema de maneira inseparável, ou seja, construindo a reparação possível no momento mesmo em que cancelava, em certos casos, os crimes cometidos, a Comissão Verdade e Reconciliação revelou ao mundo, segundo afirma Derrida, tanto os limites quanto às potencialidades éticas do perdão, na medida em que ali, por um lado, ficou claro que enquanto estivesse atado ao sistema jurídico nacional (e era imperativo que estivesse, para a sobrevivência da África do Sul como comunidade nacional democrática), o perdão - assim como a justiça - não seriam nunca mais que uma promessa, um horizonte a ser continuamente construído e buscado; por outro lado, entretanto, o trabalho da Comissão mostrou que o processo de debate e expiação pública por que passou a sociedade daquele país trouxe inúmeras conquistas, sendo que a não menor delas é o reconhecimento, na própria constituição sul-africana, dos crimes cometidos e da sua imprescritibilidade, quaisquer que fossem os arranjos políticos presentes e futuros. O dever da confissão pública, por outro lado, revelou-se também como estratégia política bastante eficiente, na medida em que obrigava o reconhecimento dos crimes no momento mesmo de seu cancelamento simbólico. A admissão, por parte do Estado e de inúmeros indivíduos conferia visibilidade às feridas vivas da comunidade sul-africana, que ainda que internacionalmente conhecidas, demandavam exposição e reconhecimento no seu próprio país. ${ }^{7}$ DERRIDA, El siglo y el perdón, op. cit., p. 8; grifo do autor.
} 
O que primeiro e de modo mais intenso chamou a atenção de Jacques Derrida foi a conexão (a dependência, talvez) do perdão com o seu contrário, o imperdoável, com os crimes que não podem ser mensurados na extensão de seus danos ou mesmo descritos apropriadamente, uma vez que, dado o seu horror, esbarram em limitações ${ }^{8}$ da linguagem e do pensamento. Tal ligação sugeria que o conceito (e também a prática) do perdão só pode tornar-se efetivo se, de algum modo, o seu contrário tiver lugar reconhecido na história e na cultura, assinalando a fronteira dos instrumentos políticos e jurídicos que por ventura regulem a sua existência. Expliquemo-nos: para Derrida, não cabe falar em perdão num ambiente (num Estado, num sistema de valores moral ou social etc.) em que as ofensas e violências praticadas ou sofridas sejam conversíveis numa determinada punição ou indenização calculável racionalmente, mediante consulta a uma imaginária tabela de valores; isto é, num universo que, de saída, institui o perdão e a prescrição do crime a partir do cumprimento de um rito social específico - seja ele jurídico (e todo o aparato do Estado moderno está fundado nessa possibilidade) ou religioso (a confissão e o exercício da penitência tornam o pecado, qualquer pecado, expiável). Tudo isso estaria confinado ao âmbito das trocas econômicas, das relações interessadas, da simples aplicação de um conjunto de leis que resolvessem, por si mesmas, os conflitos em jogo. Em nenhum dos casos listados o indivíduo ou a comunidade envolvidos teriam de confrontar-se com a necessidade de uma decisão, com o dilema (muitas vezes imponderável) de uma escolha, segundo a qual seria possível optar ou pelo perdão, que implicaria o cancelamento (entretanto precário e problemático) da dívida existente, ou pela manutenção do débito, da dor e do ressentimento havidos, mesmo que eles não possam ser, de outra maneira, saldados. Em outras palavras, e de maneira sintética: só pode ser verdadeiramente perdoado aquilo que, paradoxalmente, é imperdoável. ${ }^{9}$

O caráter aporético do perdão revela-se aí: segundo afirma o próprio Derrida, ele "só pode ser possível se é impossível", ${ }^{10}$ o que vai explicar a sua distância em relação tanto ao sistema judiciário quanto à esfera propriamente religiosa, ainda que suas raízes mergulhem na visão de mundo e na linguagem da fé. Ambas, lei e religião, pressupõem organização, trocas simbólicas, estabilidade. O perdão é acontecimento, irrupção. Não se limita ou deixa institucionalizar sem deixar de ser o que é. Sua existência é a do dom. ${ }^{11}$ Entretanto, pode ser também fruto laborioso do trabalho de um indivíduo ou nação, longo (e sempre incompleto) trabalho do luto, que apesar das feridas não cicatrizadas escolhe, afirma o perdão como caminho para a relação com o outro, como abertura infinita ao outro.

Quando pensado a partir das muitas relações que mantém com a alteridade, o perdão, na perspectiva derridiana que tem nos orientado até aqui, deve renunciar à reconciliação total, à ideia de que é possível

\footnotetext{
${ }^{8}$ Tais limitações ocuparam grande parte dos estudos literários e filosóficos das últimas décadas, dada a proliferação de relatos de situações-limite - dos quais o testemunho de Primo Levi em É isto um homem? permanece como referência e paradigma incontornável - nos quais se abordava, diretamente, a incapacidade da linguagem e da razão de lidar com eventos como o extermínio sistemático de um povo (caso da Shoah, por exemplo) ou o luto impossível dos assassinatos e desaparições de opositores levados a cabo pelas muitas ditaduras militares da América Latina. Na obra de Jacques Derrida a questão será problematizada de modo direto, ainda que não exclusivo, no livro Schibboleth - pour Paul Celan, complexa leitura da obra do poeta romeno que se realiza a partir do que nela é "résistance à la pensée" (DERRIDA, Jacques. Schibboleth. Pour Paul Celan. Paris: Editions Galilée, 2003, p. 11).

${ }^{9}$ DERRIDA, Jacques. Sob palavra. Instantâneos filosóficos. Trad. Miguel Serras Pereira. Lisboa: Ed. Fim de Século, 2004.

${ }^{10}$ DERRIDA, El siglo y el perdón, op. cit., p.13; tradução minha.

${ }^{11}$ Tema derridiano por excelência, recolhido pelo autor de estudos antropológicos como os de Marcel Mauss, o dom é tudo aquilo que se oferta espontânea e inesperadamente, sem motivação, interesse anterior ou cálculo de recompensa futura, mesmo que imaterial ou adventícia. Grande parte da reflexão ética feita pelo autor passa pela questão do dom, na medida em que toda ela vai apelar para as escolhas que o sujeito tem de fazer, para além da observação dos códigos ou normas prescritos. A ele, ao dom, são associados, entre outros, conceitos como o de justiça, alteridade, responsabilidade e, claro, perdão, desenvolvidos pelo autor em sua vasta obra.
} 
reconstituir, inteira e integralmente, a totalidade partida ${ }^{12}$; observado em relação ao outro, o perdão, segundo gostaríamos de propor, não reconcilia, não destrói nunca o que foi feito, muito embora inaugure novos laços, criando condições para a instauração de um estado de suspensão dos antigos conflitos, estado que vai por lado a lado a memória da dor e a possibilidade do esquecimento ativo, do cancelamento voluntário das violências sofridas e da atribuição de culpa. Antoine Spire, estudioso da desconstrução e entrevistador de Jacques Derrida em mais de uma oportunidade, vai analisar o perdão de modo similar ao que fazemos aqui. Depois de afirmar a ligação do conceito com o imperdoável, dirá ele: “O filósofo [Derrida] desenha assim um mundo aberto, frágil, em que o perdão pode encontrar o seu lugar sabendo contudo que nada se apaga nunca."13 Ponto comum entre as suas colocações e o raciocínio que expomos é a fragilidade do processo que se ergue em torno e dá sustentação ao edifício conceitual e performativo do perdão. Como experiência do impossível, não poderia haver nele rigidez, engessamento dogmático ou institucional. A fluidez e a precariedade são suas marcas, e só a partir delas é que pode existir.

Trata-se, como se viu até aqui, não de uma comparação entre as vantagens e desvantagens do perdoar, mas de um processo que envolve, para a sua efetivação, a visualização, a preservação permanente dos dois lados do problema. Se somente um deles figurasse no jogo de forças que envolve o perdão, tratarse-ia ou de um discurso acusatório, vitimizador, ou de uma longa lista de justificativas, nas quais se leria, algumas vezes, pedidos sinceros de desculpas, e em outras o simples cumprimento de mais um protocolo da convivência social. Nada disso é o que se vê, entretanto. O perdão, como conceito e provável práxis, surge assim, quando a digestão de um agravo, a aceitação de uma dor passada se dá concomitantemente com a exposição, o arquivamento e a reflexão sobre estes mesmos agravo e dor. É preciso lembrar, por fim, que a distinção entre pedir e conceder o perdão, nesse sentido, perde a validade, na medida em que o ato envolve sempre os dois elos da cadeia, não constituindo nunca ato isolado (mesmo que o diálogo existente entre as partes envolvidas se dê somente como discurso memorialístico, embate ficcional de pontos de vista - como no caso da obra de Graciliano Ramos, sobre a qual retomamos agora os nossos passos).

\section{Esquecer para lembrar. Lembrar para esquecer}

Infância, como mencionado, é um relato imantado por muitas das questões aqui levantadas, e que foi lido talvez de modo semelhante - sem os mesmos pressupostos teóricos, no entanto, por autores como Antonio Candido, ${ }^{14}$ G. S. Ribeiro ${ }^{15}$ e Alfredo Bosi. ${ }^{16}$ Em sua autobiografia, o escritor vai conjugar, num só lance narrativo, lembrança e esquecimento, exposição crítica da violência e desejo de rever, sob outro sistema de valores, as motivações dos homens e mulheres com que conviveu no passado. Assim como ocorre quando se instaura, num determinado evento, a possibilidade do perdão, em Infância vão atuar, sempre, estas duas forças, estes dois impulsos contrários e agônicos: de um lado a necessidade do registro, da escrita (ou da fala) como catalogação e arquivamento da dor; de outro a propensão ao descentramento e à autocrítica manifesta pelo sujeito da escrita, que não quer (ou não pode) apresentar as experiências vividas a partir de um único ponto de vista, abrindo caminho, assim, ao inesperado e ao imponderável que habitam o ato e o pensamento sobre o perdão.

${ }^{12}$ Cf. DUQUE-ESTRADA, Paulo Cesar. (org.) Espectros de Derrida. Rio de Janeiro: NAU Editora/ Ed. PUC-Rio, 2008, 15.

${ }^{13}$ SPIRE apud DERRIDA, Sob palavra, op. cit., p.111.

${ }^{14}$ CANDIDO, Antonio. Ficção e confissão. São Paulo: 34, 1992.

${ }^{15}$ RIBEIRO, G. S. Abertura entre as nuvens: uma interpretação de Infância, de Graciliano Ramos. São Paulo: Annablume, 2012.

${ }^{16}$ BOSI, Alfredo. Passagens de Infância, de Graciliano Ramos. In: Entre a literatura e a história. São Paulo: 34, 2013; p. 87-112. 
Claro está que em Infância só é possível falar do perdão senão indiretamente, tomando-o, observando-o como horizonte de reflexão e possibilidade narrativa. Todo o performativo contido no ato de pedir e conceder o perdão, toda a representação elaborada dessa cena que é possível visualizar, por exemplo, nas declarações oficiais recentes de Estados e governantes, não fazem sentido em Graciliano Ramos, na medida em que sua prosa memorialística não se dirige, mesmo que ficcionalmente, àqueles a quem o escritor gostaria, eventualmente, de perdoar ou, ainda, aqueles por quem desejaria ser perdoado. Estamos, aqui, diante de um fenômeno distinto.

Chamamos perdão, em Infância, a abertura ao outro que o processo da escrita memorialística deflagra, abertura que se dá no texto e como texto. A revisão do passado empreendida pelo narrador perfaz um primeiro movimento, um caminho obrigatório do perdoar. Para que o perdão se efetive, de uma maneira ou de outra, é preciso lançar-se para trás, voltar os olhos para o que foi feito (ou sentido): seja como impulso pessoal e particular, em que um indivíduo ou comunidade determinado olha para sua própria história a fim de analisá-la, reescrevê-la até - sem nunca a apagar, é preciso não esquecer -, seja como acontecimento abrupto e imprevisto que toma de assalto homens e mulheres, motivando-os a desfazer, mesmo parcialmente, algumas das tramas que formam o tecido-texto-passado, o perdão inscreve-se sempre como choque de tempos, uma espécie de "caminhar de costas", para dizer com Carlos Drummond de Andrade. ${ }^{17}$

Além desse elemento, o perdão, insistimos, está marcado pelo impossível e pelo paradoxo. Sua concretização e seus significados estão sempre além da razão e da lógica econômica; ele é sempre, só pode ser, dom. De modo semelhante, o livro de Graciliano vai revelar-se atravessado por essa mesma generosidade que define o dom - se é que é possível definir algo dessa natureza. A reflexão que busca conhecer e compreender os mínimos e até improváveis motivos que levaram as pessoas a escolher o caminho que escolheram, o interesse em reavaliar permanentemente a si mesmo, no intuito de despojar-se de suas próprias verdades em função da verdade múltipla e difusa do outro, tudo isso constitui a enorme disponibilidade para a diferença que caracteriza Infância, disponibilidade (abertura e afirmação) que não espera nada em troca ou se endereça a alguém em particular: simplesmente realiza-se, consumindo-se a si mesma num movimento de escrita ao mesmo tempo introspectivo, voltado para dentro, e prospectivo, voltado ao mundo exterior.

Os pais do autor, apresentados em várias passagens do livro como "entidades próximas e dominadoras", ${ }^{18}$ seres tirânicos que inspiravam medo e terror pela brutalidade dos seus castigos (físicos e psíquicos), são os personagens que mais significativamente serão revistos ao longo do livro, tendo sua imagem contraposta, de modo contínuo, ao retrato agressivo e autoritário que deles inicialmente se traçou. Todo o jogo estabelecido no texto entre lembrar e esquecer, arquivar e rasurar, narrar e refletir deixa-se capturar aqui, seja pela importância que ambos têm para o narrador, seja, principalmente, pelo cuidadoso trabalho de reaproximação que o autor vai empreendendo, entre idas e vindas, tateios e incertezas, com esses dois personagens.

A maneira gradual e até insegura com que, em determinadas passagens, o escritor busca encontrar explicações e justificativas para as ações de seus pais é exemplar, servindo de modelo (ético e estético) para muitos outros episódios do volume, conforme procuraremos demonstrar a seguir. Antes, porém, vale a pena observar com alguma atenção o papel ambíguo que os pais do protagonista têm, a fim de perceber como Graciliano reflete, à sua maneira e com os meios específicos da literatura, sobre o perdão e outros temas que lhe são afins.

\footnotetext{
${ }^{17}$ ANDRADE, Carlos Drummond. Poesia e prosa. Rio de Janeiro: Nova Aguilar, 1979, p.501.

${ }^{18}$ RAMOS, Graciliano. Infância. São Paulo: Record, 2003, p.11.
} 
Desde o primeiro capítulo do livro, "Nuvens", a imagem do pai, Sebastião Ramos, e da mãe, D. Maria Amélia, estão sugeridas segundo o esquema a que nos referimos anteriormente: a ênfase, as passagens mais longas, são todas dedicadas à representação crítica da violência que envolve e enforma tais personagens. Associada a cada bloco narrativo nos quais eles aparecem está também, sempre vai aparecer também uma passagem de reflexão, uma espécie de pausa no fluxo da narração, que ganhará uma forma, a cada caso, diferente - às vezes o comentário irônico, às vezes a digressão intimista, em outras a mirada comparatista, que busca estabelecer pontos estáveis de avaliação, mesmo sabendo-os, como muitas vezes ocorre, improváveis). Vejamos como numa das primeiras referências aos personagens o autor, com grande habilidade e senso poético, já os descreve de maneira ambígua, como se não estivesse bem certo da maneira de se aproximar deles. Referindo-se à visão disfórica que, bem ou mal, era a sua naquele tempo, o tempo do enunciado, Graciliano vai recuperando, lentamente, apenas pedaços da realidade. Nada é muito claro, apenas saltamà memória alguns elementos com os quais compor uma imagem geral:

Meu pai e minha mãe conservavam-se grandes, temerosos, incógnitos. Revejo pedaços deles, rugas, olhos raivosos, bocas irritadas e sem lábios, mãos grossas e calosas, finas e leves, transparentes. Ouço pancadas, tiros, pragas, tilintar de esporas, batecum de sapatões no tijolo gasto. Retalhos de sons dispersavam-se. Medo. Foi o medo que me orientou nos primeiros anos, pavor. ${ }^{19}$

A metonímia prevalece nesse trecho como base da estrutura narrativa. O mundo vai sendo composto (ou recomposto) aos pedaços, e a contiguidade dos seres e objetos ajuda a criança a percebê-lo. Dos pais, centro dessa passagem, restam apenas pequenos traços - todos eles, no entanto, ligados à agressividade e à violência: "olhos raivosos, bocas irritadas e sem lábios", o que antecipa a óbvia (e terrível) conclusão do narrador: "Foi o medo que me orientou nos primeiros anos, pavor." Tal sentimento, é claro, está ligado aos pais, emana deles. Entretanto, na sequência desse mesmo episódio, umas poucas frases a seguir desenham, em breve e levíssimo contraponto, uma imagem distinta desses seres autoritários e severos. Ainda num registro metonímico, em que as mãos, nuas e no entanto tão significativas, valem pela figura inteira:

Depois as mãos finas se afastaram das grossas, lentamente se delinearam dois seres que me impuseram obediência e respeito. Habituei-me a essas mãos, cheguei a gostar delas. Nunca as finas me trataram bem, mas às vezes molhavam-se de lágrimas - e os meus receios esmoreciam. As grossas, muito rudes, abrandavam em certos momentos. $\mathrm{O}$ vozeirão que as comandava perdia a aspereza, um riso cavernoso estrondava - e os perigos ocultos em todos os recantos fugiam, deixavam em sossego os viventes miúdos: alguns cachorros, um casal de moleques, duas meninas e eu. ${ }^{20}$

É instrutivo notar como é sutil a relativização que Graciliano faz da dureza dos pais. Mãos duras e grossas, olhos raivosos que, de repente, sem muitas explicações (pelo menos para a criança que, àquela altura, muito pouco entendia) amaciam-se, perdem as arestas. O registro da violência feito em Infância não chega a se quebrar, mas parece ser apenas interrompido por um "doce parêntese" ${ }^{21}$ que rapidamente torna a se fechar. Esse panorama não descreve, como à primeira vista pode parecer, a inconstância de temperamento ou mesmo o absurdo do mundo em que vivia a criança, como já foi sugerido em outro trabalho dedicado ao autor, ${ }^{22}$ segundo propomos,

\footnotetext{
${ }^{19}$ Ibidem, p. 14.

${ }^{20}$ Ibidem, p.14-15.

${ }^{21}$ Ibidem, p.22.

${ }^{22}$ Referimo-nos à dissertação de Maria das Graças de Moraes Augusto, O absurdo na obra de Graciliano Ramos ou de como um marxista se tornou existencialista, defendida no Instituto de Filosofia e Ciências Sociais (IFCS) da UFRJ no início dos anos 80. Nela, a autora procura ler a obra de Graciliano a partir das formulações conceituais de Albert Camus, com destaque para a noção de absurdo, que designa a ausência (a impossibilidade) de um sentido final para as ações humanas, determinadas, em última instância, pelas leis cegas do acaso. AUGUSTO, Maria das Graças Moraes. O absurdo na obra de Graciliano Ramos. Rio de Janeiro: IFCS, 1981 (dissertação de mestrado).
} 
a alternância entre maus tratos e doçura descrita pelo autor é fruto do esforço que ele faz para reavaliar os pais a partir de pontos de vista e valores morais distintos e menos sombrios. Como se pode perceber pela ênfase dada aos sinais da brutalidade e da rispidez, a reelaboração da imagem familiar se destina, em primeiro lugar e de maneira mais óbvia, ao registro da violência e à análise das suas consequências; só num segundo momento, no qual essa mesma violência vai ser posta em perspectiva, enquadrada num contexto mais amplo e decomposta em suas formas e estruturas, é que um novo olhar se organiza, servindo de contraponto (e antídoto) à escrita envenenada de grande parte do livro.

As justificativas e explicações, as outras leituras que Graciliano procura fazer das motivações de seus personagens constituem parte significativa das reflexões de natureza ética propostas em Infância, e isso pelo fato de que, a cada vez que esse procedimento se repete, não é apenas uma nova justificativa, uma espécie de desculpa o que emerge: para persistir na tarefa de releitura crítica do seu passado, o autor coloca, em primeiro lugar, a si mesmo (e as suas verdades) no centro do debate. Todo um doloroso processo de descentramento e autocrítica tem lugar aí, ao que se segue um questionamento dos critérios e valores que presidiram (e talvez ainda presidam) os julgamentos implícitos e explícitos feitos a respeito dos demais personagens. Nesse ponto é que a reflexão, por vezes, ganha contornos universais, aproximando-se do discurso propriamente filosófico. Desse modo, podemos dizer que se somam, no texto do escritor (não só em Infância, mas até de forma mais decisiva nas Memórias do cárcere), a análise de casos particulares, a investigação sobre o passado e a memória e, mesclada a elas, a especulação ética e axiológica.

As considerações que o narrador faz sobre sua mãe ao longo do texto ilustram o percurso que tentamos descrever, acrescentando a ele, é certo, outros tantos elementos. A irritabilidade da personagem, talvez seu traço mais saliente, é posta em destaque vezes sem conta. Sua "boca má", seus "olhos maus que em momentos de cólera se inflamavam com um brilho de loucura" ${ }^{23}$ são alguns dos índices superficiais do retrato moral que dela se oferece inicialmente. Entretanto, junto a ele surgem também ponderações deste tipo:

\begin{abstract}
Minha irmã natural se desenvolvia, recebendo com frequência arranhões nos melindres. A aversão que inspirava traduzia-se em remoques e muxoxos; quando tomava feição agressiva, fazia ricochetes e vinha atingir-nos. Se não existisse aquele pecado, estou certo de que minha mãe teria sido mais humana. De fato meu pai mostrava comportar-se bem. Mas havia aquela evidência de faltas antigas, uma evidência forte, de cabeleira negra, beiços vermelhos, olhos provocadores. Minha mãe não dispunha dessas vantagens. E com certeza se amofinava, coitada, revendo-se em nós, percebendo cá fora, soltos dela, pedaços de sua carne propícia aos furúnculos. Maltratava-se maltratando-nos. Julgo que aguentamos cascudos por não termos a beleza de Mocinha. ${ }^{24}$
\end{abstract}

Nessas observações percebemos o evidente esforço que o autor faz para justificar - diríamos mesmo compreender - algumas das deploráveis ações da personagem em relação a seus filhos e em relação a si mesma. O uso do condicional "se" e de formas dubitativas várias dão bem a medida disso, uma vez que traduzem não só a incerteza daquilo que se afirma mas, principalmente, o trabalho especulativo, a reinterpretação escrupulosa e inventiva que procura realizar.

A bela - e sintética - formulação "maltratava-se maltratando-nos" é a expressão linguística exata do que acabamos de descrever. Se em todo o raciocínio exposto por Graciliano resta, talvez, um travo determinista (mais visível ainda na re-apreciação feita dos desmandos e violências do pai), isso não altera ou invalida a reflexão que este ensaio propõe: segundo acreditamos, é o gesto em si da reavaliação das motivações dos personagens, e não os seus resultados imediatos, o que deve ser levado em conta, na

\footnotetext{
${ }^{23}$ RAMOS, op. cit., p. 16.

${ }^{24}$ Ibidem, p.26; grifo nosso.
} 
medida em que o problema do perdão, que se insinua aqui, depende mais do desejo do que da razão, isto é, do endereçar-se a ele do que das justificativas que podem surgir para mascarar o seu gesto imponderável. Sobre o pai, "homem sério, de testa larga, (...) dentes fortes, queixo rijo, fala tremenda" 25 , Graciliano vai realizar estudo similar, ampliando apenas o escopo da reflexão que faz sobre as motivações do personagem. Enquanto as agressões da mãe resumiam-se, na maior parte das vezes, à extrema impaciência e à hostilidade mais ou menos velada que se manifestava, entre outras coisas, por meio dos apelidos ofensivos que dava ao menino (cabra-cega e bezerro-encourado), a violência paterna não se restringia a xingamentos ou demonstrações de desafeto. Surras e castigos físicos de todo tipo são os instrumentos privilegiados com que ele exercia e conservava o seu poder sobre a criança e os demais "viventes miúdos"26 que dependiam dele para seu sustento.

Num movimento que combina a alternância estratégica de tempos e pontos de vista, o narrador vai elaborando - à medida mesmo em que narra os desmandos do personagem - algumas hipóteses sobre o seu comportamento, algumas assertivas que procuram dar conta da complexidade de motivos que cercavam o indivíduo. O centro de suas considerações agora se desloca do campo afetivo para o econômico, das particularidades da vida conjugal para um contexto social mais amplo, que envolve política, propriedade e poder. Depois de relatar o fracasso da empreitada agropecuária da sua família (obviamente capitaneada por Sebastião Ramos), o narrador começa a mostrar um aspecto diferente do personagem, aspecto que, no momento em que se deram esses acontecimentos, muito o surpreendeu: "Sentado junto aos instrumentos agrícolas, em desânimo profundo, as mãos inertes, pálido, o homem agreste murmurava uma confissão lamentosa à companheira. (...) O desalento e a tristeza abalaram-me". ${ }^{27}$

Como se vê, o narrador, reconstituindo o olhar da criança, sente-se confuso diante da nova realidade: o homem "terrivelmente poderoso, e essencialmente poderoso" 28 que, de tempos em tempos, o atormentava por coisas mesquinhas, perdia a força, reduzia-se, não era mais que "um gibão roto sobre a camisa curta". ${ }^{29}$ Levado, talvez, por essa recordação, mas sem dúvida alguma motivado pelo desejo de reaproximar-se, no texto e pelo texto, dos habitantes de seu passado, o narrador ensaia respostas. O que chamará de "explicação" 30 para os atos do pai são, na verdade, mais uma reflexão em processo, que se desenrola em torno de um problema, do que uma solução definitiva e uma explicação final. Vejamos como ela se apresenta: o contraste entre tempos é a chave estrutural (temática e formal) para as suas formulações.

Na rua examinei [refere-se, claro está, ao tempo do enunciado] o ente sólido, áspero com os trabalhadores, garboso nas cavalhadas. Vi-o arrogante, submisso, agitado, apreensivo - um despotismo que às vezes se encolhia, impotente e lacrimoso. A impotência e as lágrimas não nos comoviam. Hoje acho naturais as violências que o cegavam. Se ele estivesse embaixo, livre de ambições, ou em cima, na prosperidade, eu e o moleque José teríamos vivido em sossego. Mas no meio, receando cair, avançando a custo, perseguido pelo verão, arruinado pela epizootia, indeciso, obediente ao chefe político, à justiça e ao fisco, precisava desabafar, soltar a zanga concentrada. (...) Venerava o credor e, pontual no pagamento, economizava com avareza. Só não economizava pancadas e repreensões. Éramos repreendidos e batidos. ${ }^{31}$

Por um lado, é nítida a ambiguidade, para Graciliano, do ato em marcha. Em momento algum do longo trecho apresentado o escritor cede à piedade fácil ou ao sentimentalismo nostálgico, que tenderiam

\footnotetext{
${ }^{25}$ Ibidem, p. 16.

${ }^{26}$ Ibidem, p. 15.

${ }^{27}$ Ibidem, p.31.

${ }^{28}$ Ibidem, p.30.

${ }^{29}$ Ibidem, p.31.

${ }^{30}$ Ibidem.

${ }^{31}$ Ibidem, grifo nosso.
} 
a tudo condenar ou tudo redimir, sem meios-termos. Sua postura é lúcida e o viés crítico de sua escrita se mantém alerta. Ao lado das justificativas e da reconsideração, a memória da dor persiste: "éramos repreendidos e batidos". A tensão parece nunca resolver-se, mantendo-se em suspensão indefinida, sem saída. Por outro lado, se atentarmos para o substrato da análise empreendida pelo autor, encontraremos mais uma vez (e em certo sentido de maneira até amplificada) a visão de mundo determinista, o ranço mecanicista da leitura que vê os homens, sempre e em graus variados, sobredeterminados pelo trabalho ou pelos meios econômicos em que estão imersos.

De forma sintética, é possível afirmar que, mesmo analisando com esses instrumentos os seus personagens, Graciliano não os vê, e nem a si mesmo - um outro ser de papel em Infância - integralmente assim. A possibilidade da escolha e da surpresa parecem sempre abertas, apesar dos horizontes muitas vezes carregados. A construção das identidades (e não sua mimese estabilizadora), a memória como invenção: duas das questões fundamentais da escrita reflexiva de Infância. A comparação de seu pai ou de outras figuras violentas do livro com personagens como José Leonardo ou José da Luz, por exemplo, ilustram isso. Ambos, vivendo num contexto social e econômico parecido com o que o seu pai viveu e criou os filhos, assumiram posturas diferentes, afirmaram valores distintos. A própria atitude do escritor, um homem marcado definitivamente pelos rigores da educação sertaneja, por um lado, e pelo autoritarismo e pelas tempestades políticas da sua época, por outro, contraria a perspectiva determinista. Ao invés de oferecer, como resposta às desgraças vistas e vividas, uma obra na qual o ressentimento e a autocomiseração operassem como articuladores da criação literária, o autor escolhe um percurso distinto, no qual assume a criação de textos cuja marca é, justamente, a diferença, a abertura ao outro.

$\mathrm{O}$ gesto de Graciliano, nesse trecho em foco e em várias outras passagens do livro, é tudo. Assim como havia feito, em registro diverso, com Pe. João Inácio, a professora D. Maria do O, Fernando e mesmo com sua mãe, D. Maria Amélia, o escritor busca compreender o pai, por mais que não lhe faltassem motivos para simplesmente condená-lo. Em meio às lembranças dolorosas que a escrita deflagra, sua atenção parece estar concentrada em outro lugar, suas forças dirigidas para diferente objetivo: perdoar os homens e mulheres que o maltrataram, buscando, para isso, refletir sobre a condição particular de cada um daqueles indivíduos, observando-os além "[d]essas bainhas em que a sociedade os prendeu". ${ }^{32}$

Não se trata de um perdão condicional, uma espécie de concessão caridosa que o autor faz a pessoas que precisariam, de um modo ou de outro, ter o seu valor provado para fazerem jus ao que a eles era ofertado. Não se trata também de um perdão que a tudo reconciliaria, numa tentativa totalizadora de atar as duas pontas da vida num só laço metafísico. Nada disso. A compreensão dos seus atos, a busca (a invenção) por justificativas que procurassem escusar, de alguma maneira, os personagens foi o caminho encontrado por Graciliano para reaproximar-se de seu passado, sem contudo pretender esgotar as contradições que tanto a atividade memorialística quanto a análise detalhada das motivações alheias poderiam suscitar. Num escritor cuja capacidade e disposição para a crítica (e a autocrítica) sempre foram tão agudas, seria demasiado ingênuo supor um desejo de resgate integral e apaziguador de eventos passados e traumáticos. A surpresa e o abalo foram as imagens privilegiadas por ele para descrever o jogo de forças posto em marcha em Infância, no qual delineiam-se, em caracteres bem marcados, a lembrança da dor e o esforço por perdoar, aporeticamente sem reconciliar ou esquecer nada, aqueles que algum dia o aterrorizaram.

Recebido em: 29/03/2015.

Aprovado em: 15/12/2016

${ }^{32}$ RAMOS, Graciliano. Memórias do cárcere. São Paulo: Record, 2008, p.13. 